\title{
Small intestine peroral biopsy in coeliac children
}

\author{
WILFRID SHELDON AND EDWARD TEMPANY \\ From The Hospital for Sick Children, Great Ormond Street, London
}

EDITORIAL COMMENT Peroral biopsy of the small intestine is much more difficult and not without risk in coeliac children. Valuable scientific data are recorded in this paper but the authors consider that the investigation is now outside the scope of routine investigations.

Since the original description of small intestine biopsy in a coeliac child by Sakula and Shiner (1957) much has been written about this method of investigation, more as it relates to adults than to children. It is our purpose to record our experience with this technique at The Hospital for Sick Children, Great Ormond Street. Although we have studied several other conditions by this method, we shall limit our remarks to children with gluten intolerance (coeliac disease), except to give an account of one child with lactose intolerance in whom biopsy caused perforation.

The diagnosis of coeliac disease rested on the usual criteria of clinical history and physical examination, supported by a variety of investigations, including fat balances, 24-hour faecal fat estimations, glucose tolerance curves, Figlu tests, barium studies of the small gut, and response to a glutenfree diet and often relapse of symptoms on restoring gluten to the diet.

Between 1958 and 1964, 92 successful biopsies were performed in coeliac children. The first 29 were carried out, under general anaesthesia by Dr. Margot Shiner, using the tube which bears her name, and we are much indebted to her. However, in other hands her tube proved too difficult, which was also the experience of Cameron, Astley, Hallowell, Rawson, Miller, French, and Hubble (1962) who reported seven failures out of 13 attempts on children. For our remaining 63 successful biopsies (performed by Dr. Fry, Dr. J. A. Black, and Dr. Tempany) the Crosby-Kugler (1597) capsule was used, as a rule without sedation. We have had no experience with the Rubin tube (Brandborg, Rubin, and Quinton, 1959).

\section{FAILURE RATE}

In this communication we use the term 'successful' biopsy to imply that a specimen of intestinal mucosa suitable for histological and histochemical study was obtained, irrespective of whether any complications arose. Few authors give figures for the rate of failure to obtain a satisfactory specimen, but for the child on whom a tube is to be passed the discomfort and apprehension is unrelated to the success of the investigation, and to our mind it is necessary to report the failure rate because it must have a bearing on the indications that justify submitting a child to this procedure. Using the Crosby capsule, Cameron et al. (1962) reported 11 failures out of 57 attempts $(19 \%)$ in children who were under fairly heavy sedation. We have been less fortunate; our 63 successful biopsies with the Crosby capsule entailed 97 attempts, giving a failure rate of $35 \%$; the failure rate for the children biopsied for us by Dr. Shiner was $34 \%$. The number of cases is too small to draw any firm conclusion about the influence of the child's age on the likelihood of success; it can, however, be said that in our series the failure rate in children under 5 years was approximately double that in older children and that we were slightly more successful in children under 2 years than in those in the 2-5-year group.

Inability to get the capsule to pass through the pylorus proved to be the most frequent cause of failure; in others the capsule failed to fire, being sometimes blocked with mucus.

The procedure would seem to be easier in adults; out of 700 intubations in adults, Sheehy (1964) reported a failure rate of $6 \%$.

\section{TECHNIQUE}

All children before biopsy had a haemoglobin estimation, prothrombin index, and thromboplastin generation test carried out. The patient was fasted for at least six hours. The tubing used was polyethelene PE200. In children below $16 \mathrm{lb}$. in weight the infant-sized Crosby capsule was used. In heavier children the adult-sized capsule was employed. Older children sometimes found difficulty in swallowing the capsule and these were given Amethocaine lozenges to suck for 20 minutes beforehand. 
To children considered excitable mild sedation in the form of chloral (300 mg. to those under 2 years, $600 \mathrm{mg}$. to children between 2 and 5 years) was given an hour before the procedure. Swallowing of the capsule was achieved with the child sitting on a nurse's lap, and the patient was then returned to bed to lie on the right side, with a nurse in constant attendance. The position of the capsule was confirmed radiologically, the time to do this being judged by the length of tubing projecting from the mouth and usually by bile draining freely from the tubing. After injecting $2 \mathrm{ml}$. of Gastrografin down the tubing, a straight film of the abdomen was taken with the child lying prone, and the tube was then flushed out with $5 \mathrm{ml}$. of normal saline. When the capsule was satisfactorily positioned it was fired by applying strong rapid suction with a $20 \mathrm{ml}$. syringe.

Following biopsy a close watch was kept on the pulse rate, which was recorded every 15 minutes for four hours, then half-hourly for the next four hours, and hourly for the subsequent eight hours. A liquid or semi-liquid diet was given until the morning after biopsy when a straight radiograph of the abdomen was taken, to exclude the presence of air under the diaphragm.

\section{COMPLICATIONS}

The three main complications are incomplete severance of the biopsy specimen so that the capsule remains attached to the mucosa and cannot be withdrawn, haemorrhage, and perforation. Hubble (1963) reported that in more than 150 biopsies on children, which included the series described by Cameron et al., in one child the capsule remained attached to the mucosa for more than 24 hours; one child had a localized ileus with fever and pain; and one developed peritonitis which resolved without surgery. Shackleton and Haas (1962) described fatal peritonitis in a girl of 18 months. Sheehy (1964) referred to perforation in a child of 8 years. In our series, the capsule remained attached to the mucosa in a girl of 9 years, and was eventually passed per rectum three days later after she had been allowed to swallow the tubing. In a 12-monthold boy biopsy was followed by melaena, the haemoglobin dropping from 70 to $49 \%$. We have had one experience of perforation in a boy aged 20 months, suffering from lactose intolerance, from whom a normal biopsy was obtained. Two hours after biopsy he was reported to be complaining of pain and his pulse rate was rising. In the absence of physical signs, a radiograph showed a small collection of air in the peritoneum. Laparotomy was performed within four hours of biopsy and a perforation was found in the region of thelower jejunum. Fortunately he made an uninterrupted recovery.

\section{INVESTIGATION OF BIOPSY MATERIAL}

DISSECTION MICROSCOPY Immediately the biopsy is obtained the specimen may be mounted with the mucosal surface upwards and examined under the dissecting microscope. The appearances have been described by Rubin, Brandborg, Phelps, and Taylor (1960a) and by Holmes, Hourihane, and Booth (1961). In health the beautiful and characteristic appearance of the villi massed together can be likened to fingers viewed on end. According to the degree of villous atrophy, typical of untreated coeliac disease, the gross surface appearance varies from a whorled or ridged pattern, in the less severe cases, to a granular or flat surface, in the most severe. Dissection microscopy offers a rapid but only approximate appraisal of what the microscopical appearance is likely to be.

HISTOLOGY There is general agreement about the histological appearances of the mucosa in coeliac disease, early descriptions having been given by Shiner (1960), by Rubin et al. (1960), and by Anderson (1960). The changes consist of a loss of surface area owing to shortening or disappearance of the villi, the latter giving a flat surface to the gut. There is also increased cellular infiltration in the lamina propria. We are in complete agreement with these descriptions. The term 'subtotal villous atrophy' has been applied when the surface is flat; in 'partial villous atrophy, the villi are shorter and broader than normal and may be forked. The limits of partial villous atrophy especially towards normality, are difficult to define, and for our convenience we identify a group we have termed 'near normal' in which the villi appear only slightly broader or shorter than normal and there is little cellular infiltration. Although others (Rubin et al., 1960b; Thurlbeck, Benson, and Dudley, 1960; and Cameron et al., 1962) have considered that the word atrophy is not strictly applicable to the changes seen in the villi, a contention we support, we use it in this communication in order to conform with the reports of other investigators.

\section{RESULTS}

Our results are recorded in Table $I$, and can be divided into three groups.

GROUP 1: BIOPSY BEFORE BEGINNING A GLUTEN-FREE DIET Thirty-one children came into this group, their ages ranging from 9 months to 13 years. Twenty-three of them were below 2 years of age. In 27 the histological changes were those of subtotal villous atrophy, and the remaining four showed partial villous atrophy. The sections were examined by two observers independently, and the changes were unmistakable. We conclude that when the diagnosis of untreated coeliac disease is in doubt, 
TABLE I

RESULTS OF SMALL INTESTINE BIOPSIES

\begin{tabular}{|c|c|c|c|c|c|c|c|}
\hline \multirow{2}{*}{$\begin{array}{l}\text { Reference } \\
\text { Number }\end{array}$} & \multirow[t]{2}{*}{ Sex } & \multirow{2}{*}{$\begin{array}{l}\text { Age } \\
\text { at First } \\
\text { Biopsy }\end{array}$} & \multirow{2}{*}{$\begin{array}{l}\text { Group I } \\
\text { Before } \\
\begin{array}{l}\text { Gluten-free } \\
\text { Diet }\end{array}\end{array}$} & \multicolumn{2}{|l|}{ Group II } & \multicolumn{2}{|l|}{ Group III } \\
\hline & & & & $\begin{array}{l}\text { During } \\
\text { Gluten-free } \\
\text { Diet }\end{array}$ & $\begin{array}{l}\text { Period } \\
\text { on Diet }\end{array}$ & $\begin{array}{l}\text { After } \\
\text { Return to } \\
\text { Normal Diet }\end{array}$ & $\begin{array}{l}\text { Period } \\
\text { on Normal } \\
\text { Diet }\end{array}$ \\
\hline $\begin{array}{l}351876 \\
364515 \\
363295 \\
332874 \\
359979 \\
368810 \\
359600 \\
351508 \\
313057 \\
333582\end{array}$ & $\begin{array}{l}\text { M. } \\
\text { M. } \\
\text { M. } \\
\text { M. } \\
\text { M. } \\
\text { F. } \\
\text { F. } \\
\text { F. } \\
\text { M. } \\
\text { F. }\end{array}$ & $\begin{array}{r}9 / 12 \\
9 / 12 \\
9 / 12 \\
10 / 12 \\
11 / 12 \\
12 / 12 \\
12 / 12 \\
13 / 12 \\
13 / 12 \\
13 / 12\end{array}$ & $\begin{array}{l}\text { S.V.A. } \\
\text { S.V.A. } \\
\text { S.V.A. } \\
\text { S.V.A. } \\
\text { S.V.A. } \\
\text { S.V.A. } \\
\text { S.V.A. } \\
\text { P.V.A. } \\
\text { S.V.A. } \\
\text { S.V.A. }\end{array}$ & Normal & $\begin{array}{c}7 / 12 \\
1 \cdot 9 / 12\end{array}$ & & \\
\hline 317264 & M. & $14 / 12$ & S.V.A. & $\left\{\begin{array}{l}\text { S.V.A. } \\
\text { P.V.A. }\end{array}\right.$ & $\begin{array}{l}12 / 12 \\
34\end{array}$ & & \\
\hline $\begin{array}{l}338255 \\
360209 \\
370881 \\
365820 \\
373680 \\
355934 \\
353444 \\
332850\end{array}$ & $\begin{array}{l}\text { M. } \\
\text { M. } \\
\text { F. } \\
\text { M. } \\
\text { F. } \\
\text { M. } \\
\text { F. } \\
\text { F. }\end{array}$ & $\begin{array}{l}14 / 12 \\
15 / 12 \\
15 / 12 \\
16 / 12 \\
17 / 12 \\
18 / 12 \\
18 / 12 \\
18 / 12\end{array}$ & $\begin{array}{l}\text { S.V.A. } \\
\text { S.V.A. } \\
\text { S.V.A. } \\
\text { S.V.A. } \\
\text { S.V.A. } \\
\text { S.V.A. } \\
\text { S.V.A. } \\
\text { P.V.A. }\end{array}$ & $\begin{array}{l}\text { P.V.A. } \\
\text { S.V.A. } \\
\text { S.V.A. }\end{array}$ & $\begin{array}{l}24 \\
3 / 12 \\
4 / 12\end{array}$ & & \\
\hline 324613 & M. & $20 / 12$ & S.V.A. & $\left\{\begin{array}{l}\text { P.V.A. } \\
\text { P.V.A. }\end{array}\right.$ & ${ }_{21}^{7 / 12}$ & & \\
\hline $\begin{array}{l}338403 \\
354145\end{array}$ & $\begin{array}{l}F . \\
F .\end{array}$ & $\begin{array}{l}20 / 12 \\
21 / 12\end{array}$ & $\begin{array}{l}\text { S.V.A. } \\
\text { S.V.A. }\end{array}$ & P.V.A. & 24 & & \\
\hline 319781 & F. & $21 / 12$ & S.V.A. & $\left\{\begin{array}{l}\text { P.V.A. } \\
\text { P.V..A }\end{array}\right.$ & $\begin{array}{r}6 / 12 \\
14 / 12\end{array}$ & S.V.A. & $5 / 12$ \\
\hline 300743 & M. & $2 \cdot 4 / 12$ & S.V.A. & $\left\{\begin{array}{l}\text { P.V.A. } \\
\text { N.N. }\end{array}\right.$ & $\begin{array}{l}2 \frac{1}{2} \\
3 \frac{1}{2}\end{array}$ & S.V.A. & $2 / 12$ \\
\hline $\begin{array}{l}337622 \\
355888 \\
321187 \\
356960 \\
364295 \\
363815 \\
334671\end{array}$ & $\begin{array}{l}\text { F. } \\
\text { M. } \\
\text { M. } \\
\text { M. } \\
\text { F. } \\
\text { F. } \\
\text { F. }\end{array}$ & $\begin{array}{c}2 \cdot 8 / 12 \\
3 \cdot 2 / 12 \\
5 \cdot 10 / 12 \\
6 \frac{1}{2} \\
7 \frac{1}{4} \\
11 \frac{8}{4} \\
13 \frac{1}{2}\end{array}$ & $\begin{array}{l}\text { P.V.A. } \\
\text { S.V.A. } \\
\text { S.V.A. } \\
\text { S.V.A. } \\
\text { S.V.A. } \\
\text { S.V.A. } \\
\text { P.V.A. }\end{array}$ & P.V.A. & $4 / 12$ & & \\
\hline $\begin{array}{l}356318 \\
332670\end{array}$ & $\begin{array}{l}\text { F. } \\
\text { F. }\end{array}$ & $\begin{array}{l}10 / 12 \\
11 / 12\end{array}$ & & $\begin{array}{l}\text { S.V.A. } \\
\text { S.V.A. }\end{array}$ & $\begin{array}{l}1 / 12 \\
2 / 12\end{array}$ & & \\
\hline 353386 & M. & $13 / 12$ & & $\left\{\begin{array}{l}\text { S.V.A. } \\
\text { P.V.A. } \\
\text { S.V.A. }\end{array}\right.$ & $\begin{array}{l}1 / 12 \\
4 / 12 \\
1 / 12\end{array}$ & & \\
\hline 328444 & M. & $16 / 12$ & & $\left\{\begin{array}{l}\text { P.V.A. } \\
\text { N.N. } \\
\text { S.V.A. }\end{array}\right.$ & $\begin{array}{l}1 \cdot 9 / 12 \\
28 \\
1 / 12\end{array}$ & & \\
\hline 321906 & M. & $1.9 / 12$ & & $\left\{\begin{array}{l}\text { S.V.A. } \\
\text { Normal }\end{array}\right.$ & $\begin{array}{c}1 / 12 \\
4\end{array}$ & S.V.A & $9 / 12$ \\
\hline $\begin{array}{l}372123 \\
301878 \\
315468\end{array}$ & $\begin{array}{l}\text { M. } \\
\text { F. } \\
\text { M. }\end{array}$ & $\begin{array}{r}24 \\
3 \\
3 \frac{1}{2}\end{array}$ & & $\begin{array}{l}\text { S.V.A. } \\
\text { N.N. } \\
\text { P.V.A. }\end{array}$ & $\begin{array}{l}6 / 12 \\
1 \cdot 9 / 12 \\
7 / 12\end{array}$ & & \\
\hline 275491 & M. & $5 \frac{1}{2}$ & & $\left\{\begin{array}{l}\text { P.V.A. } \\
\text { P.V.A. }\end{array}\right.$ & $\begin{array}{l}5 / 12 \\
1 \cdot 6 / 12\end{array}$ & & \\
\hline 333064 & F. & $5 \frac{1}{2}$ & & $\left\{\begin{array}{l}\text { N.N. } \\
\text { S.V.A. }\end{array}\right.$ & $\begin{array}{l}3 \cdot 2 / 12 \\
1 / 12\end{array}$ & & \\
\hline 316164 & F. & $6 \cdot 11 / 12$ & & $\left\{\begin{array}{l}\text { P.V.A. } \\
\text { Normal }\end{array}\right.$ & $\begin{array}{l}8 / 12 \\
2 \frac{1}{2}\end{array}$ & & \\
\hline $\begin{array}{l}257557 \\
299634 \\
332879\end{array}$ & $\begin{array}{l}\text { F. } \\
\text { M. } \\
\text { M. }\end{array}$ & $\begin{array}{c}8 \\
81 \\
104\end{array}$ & & $\begin{array}{l}\text { P.V.A. } \\
\text { S.V.A. } \\
\text { P.V.A. }\end{array}$ & $\begin{array}{l}2 \\
14 / 12 \\
6 / 12\end{array}$ & & \\
\hline 194432 & F. & $11 \cdot 4 / 12$ & & $\left\{\begin{array}{l}\text { S.V.A. } \\
\text { Normal }\end{array}\right.$ & $\begin{array}{l}5 / 12 \\
1 \cdot 6 / 12\end{array}$ & & \\
\hline $\begin{array}{l}270750 \\
200283 \\
309403\end{array}$ & $\begin{array}{l}\text { F. } \\
\text { F. } \\
\text { M. }\end{array}$ & $\begin{array}{l}12 \cdot 4 / 12 \\
12 \frac{1}{2} \\
12 \frac{3}{4}\end{array}$ & & $\begin{array}{l}\text { P.V.A. } \\
\text { S.V.A. } \\
\text { N.N. }\end{array}$ & $\begin{array}{l}12 / 12 \\
3 \\
3\end{array}$ & P.V.A. & $2 / 12$ \\
\hline $\begin{array}{l}304397 \\
280013 \\
256148 \\
200102 \\
206887 \\
206349\end{array}$ & $\begin{array}{l}\text { F. } \\
\text { M. } \\
\text { M. } \\
\text { F. } \\
\text { F. } \\
\text { M. }\end{array}$ & $\begin{array}{l}5 \\
5 \frac{3}{4} \\
9 \frac{1}{2} \\
10 \frac{1}{2} \\
11 \cdot 5 / 12 \\
11 \frac{3}{4}\end{array}$ & & & & $\begin{array}{l}\text { S.V.A. } \\
\text { S.V.A. } \\
\text { S.V.A. } \\
\text { Normal } \\
\text { P.V.A. } \\
\text { S.V.A. }\end{array}$ & $\begin{array}{l}2 \\
2 \\
1 \\
7 \\
6 \frac{1}{2} \\
9 / 12\end{array}$ \\
\hline 202796 & M. & $11 \cdot 11 / 12$ & & & & $\left\{\begin{array}{l}\text { P.V.A. } \\
\text { S.V.A. }\end{array}\right.$ & $\begin{array}{l}17 / 12 \\
4\end{array}$ \\
\hline 296750 & F. & $13 \cdot 4 / 12$ & & & & S.V.A. & $2 \frac{1}{2}$ \\
\hline
\end{tabular}


small intestine biopsy offers a reliable means of confirming or refuting the diagnosis. This does not imply that villous atrophy is confined to coeliac disease, for it has been described in tropical sprue (Rubin, 1961) in giardiasis (Cameron et al, 1962), in secondary steatorrhoea with macrocytic anaemia (Shiner and Doniach, 1960), and in surgical specimens (Townley, Cass, and Anderson, 1964); nor does it mean that every child on whom a diagnosis of coeliac disease is made should undergo biopsy in order to confirm the diagnosis, for often this can be reached on clinical grounds coupled with other laboratory investigations without submitting the child to biopsy procedure with its possible hazards. Our findings in this group confirm those of previous writers (Anderson, 1960; Cameron et al., 1962; Rubin, 1961).

GROUP II: BIOPSY DURING TREATMENT WITH A GLUTENFREE DIET Table I shows that there were 31 children in this group, of whom 13 had had a previous biopsy as members of group $I$, and 10 underwent two or three biopsies during the period of treatment. Five of the children had only been under treatment for one month, and must, therefore, correspond closely to those in group I; all five showed subtotal villous atrophy. In five others the mucosa had reverted to normal after treatment had lasted respectively for 18 months, 21 months, 21 months, two and a half years, and four years, but it is of course impossible to say for how long the mucosa had been normal before the biopsy was carried out. Mucosal improvement short of becoming normal occurred in 10 children after a period of treatment varying from four months to three years, but in others subtotal atrophy persisted without apparent improvement for a year or more; indeed in one child this degree of atrophy was still present after three years of treatment. We have concluded that although histological improvement in the mucosa may occur during gluten-free treatment, even to the extent of the mucosa appearing normal, this does not invariably happen. There seems to be no clear relationship between the speed and degree of clinical benefit conferred by gluten-free treatment and mucosal improvement.

Similar views have been previously expressed by other investigators. Thus Anderson (1960) recorded a child whose mucosa became normal after treatment for three months, and Yardley, Bayless, Norton, and Hendrix (1962) reported histological improvement in three coeliac patients within three to six days of starting a gluten-free diet, but these authors, and also Hubble (1963), concluded that mucosal improvement and clinical benefit did not move in a parallel relationship. Shiner and Birbeck (1961) reported a normal mucosa in three coeliac patients after treatment had persisted for four to six years, but in a later communication Madanagopalan, Shiner, and Rowe (1965), after conducting careful measurements of the total mucosal thickness, height and width of the villi, and height of the surface cells, concluded that although the mucosa could improve under the influence of a gluten-free diet, it remained abnormal. Rubin et al. (1960a) have suggested that lack of correlation between biopsy appearances and the clinical state is because the length of affected gut is of greater importance than the degree of change in the fragment examined at biopsy.

GROUP III : BIOPSY SUBSEQUENT TO RESUMING A NORMAL DIET Twelve children came within this group, of whom four had had a previous biopsy while on a gluten-free diet. Only one showed a normal mucosa; she was then $10 \frac{1}{2}$ years old and had been on a normal diet for seven years, and throughout this period her health had been good, her temperament happy, and her rate of growth satisfactory. The mucosa in the other 11 children showed partial villous atrophy in two, and subtotal villous atrophy in nine; nevertheless two of these children (one with partial the other with subtotal villous atrophy) have made satisfactory clinical progress during their four years and six years respectively on a normal diet. The remaining nine children have shown themselves to be intolerant of gluten, although in two of them the evidence of intolerance was confined to failure to maintain their gradient of growth.

This small group offers answers to two practical questions. Does the return of the mucosa to normal during gluten-free treatment indicate that gluten tolerance has been achieved, and that a normal diet will henceforth be well tolerated? The answer is No, and is exemplified by the history of two children. In one the mucosa had reverted from 'near normal' to subtotal villous atrophy two months after resuming a normal diet, and within two weeks this child was passing large, pale, offensive stools and his abdomen was distending; in the other the mucosa had reverted from normal to subtotal villous atrophy after nine months on a normal diet, and during this time his gradient of growth had fallen from the 50th to the 30th percentile, the stools had become pale and loose, and his temperament had deteriorated.

Can a child maintain satisfactory progress on a normal diet even if the mucosa is abnormal? It would seem so, for we have already described two children in group III who achieved this.

We have concluded that biopsy is of little value as a means of deciding when to attempt a return to 
a normal diet. This still remains a matter of trial and error. Biopsy might be of help when there is difficulty in deciding on clinical grounds whether a normal diet is being properly tolerated, for we have not known of a child in whom a normal biopsy has been associated with inability to tolerate gluten, but at this stage in the management of the illness biopsy for this purpose should seldom be necessary. The clinical evidence of intolerance may lie in a return of such abdominal symptoms as discomfort, distension, and the passage of pale loose stools, or by a failure to maintain the previous rate of growth; or by temperamental deterioration; or by a combination of these. Provided the child remains under adequate observation, the recognition of persistent gluten intolerance should not give rise to difficulty; if it is present, the clinical condition will quickly improve again when gluten is withheld.

\section{ELECTRON MICROSCOPY}

Our investigations have not included electron microscopy, but several observers (Hartman, Butterworth, Hartman, Crosby, and Shirai, 1960, Zetterqvist and Hendrix, 1960 Ashworth, Chears, Sanders, and Pearce, 1961 Shearman, Girdwood, Williams, and Delamore, 1962) have reported that when there is villous atrophy the microvilli which line the epithelial cells of the small gut are sparse, stunted, and irregular in shape and spacing.

\section{HISTOCHEMISTRY}

Padykula, Strauss, Ladman, and Gardner (1961) reported that the flat surface epithelium in 13 cases of 'non-tropical sprue' was deficient in succinic dehydrogenase, esterase, acid phosphatase, and adenosine triphosphatase, and Spiro, Filipe, Stewart, Booth, and Pearse, (1964), in a study of a wide range of enzymes, found that in the mucosa of the small intestine in patients with idiopathic steator- rhoea many enzymes were lacking in normal activity, with the exception of alkaline phosphatase which was relatively unaffected. The histochemical reactions tended to be stronger in those patients who had been treated on a gluten-free diet, there being a rough relation between the morphological appearances of the villi and their histochemical reactions. They pointed out that sampling errors with such small pieces of biopsy tissue would help to explain the variations that occurred in the histochemical results. Filipe (1962) considered that the enzyme changes were probably secondary to the morphological findings.

In our series, histochemical studies were made on 32 biopsies taken from 28 children. Five of these studies were undertaken by Dr. R. M. H. McMinn at King's College, London, the remainder by Dr. B. D. Lake of the Department of Morbid Anatomy at Great Ormond Street, to both of whom we are very grateful.

Table II shows the results obtained from 11 coeliac children before they began treatment with a gluten-free diet. It will be seen that of the enzymes studied there was a general reduction in their activity; in two instances succinic dehydrogenase was present in normal amount, but in both of these the other enzymes were reduced.

Table III gives the results obtained from 15 biopsies on 14 children, performed during the course of treatment on a gluten-free diet. The analyses have been set out in a chronological order according to the length of time for which treatment had been maintained. In no case was any enzyme reported as absent; reduction in the amount of enzyme was recorded on 28 occasions compared with a normal amount on 39 occasions. The likelihood of an enzyme being present in normal amount was significantly greater when dietetic treatment had persisted for more than a year (12 cases) than when it had been employed for less than six months (4 cases), giving the impression that recovery of enzyme

TABLE II

HISTOCHEMICAL FINDINGS BEFORE TREATMENT WITH A GLUTEN-FREE DIET

\begin{tabular}{|c|c|c|c|c|c|c|}
\hline Reference No. & $\begin{array}{l}\text { Succinic } \\
\text { Dehydrogenase }\end{array}$ & Aminopeptidase & Acid Phosphatase & $\begin{array}{l}\text { Non-specific } \\
\text { Esterase }\end{array}$ & a-Glucosidase & $\begin{array}{l}\text { Glucose-6- } \\
\text { phosphatase }\end{array}$ \\
\hline $\begin{array}{l}338255 \\
338891 \\
332850 \\
355934 \\
351876 \\
354145 \\
355888 \\
356960 \\
337622 \\
351508 \\
360209\end{array}$ & $\begin{array}{l}\text { Absent } \\
\text { Reduced } \\
\text { Reduced } \\
\text { Reduced } \\
\text { Reduced } \\
\text { Reduced } \\
\text { Reduced } \\
\text { Reduced } \\
\text { Normal } \\
\text { Reduced } \\
\text { Normal }\end{array}$ & $\begin{array}{l}- \\
\text { Reduced } \\
\text { Reduced } \\
\text { Reduced } \\
\text { Reduced } \\
\text { Reduced } \\
\text { Reduced } \\
\text { Reduced } \\
\text { Reduced } \\
\text { Reduced }\end{array}$ & $\begin{array}{l}- \\
\overline{-} \\
\text { Reduced } \\
\text { Reduced } \\
\overline{-} \\
\overline{-} \\
\text { Reduced } \\
\text { Reduced } \\
\text { Reduced }\end{array}$ & $\begin{array}{l}- \\
\overline{-} \\
\text { Reduced } \\
- \\
\overline{-} \\
\overline{-} \\
\text { Reduced } \\
\text { Reduced } \\
\text { Reduced }\end{array}$ & $\begin{array}{l}- \\
\overline{-} \\
\text { Reduced } \\
- \\
\overline{-} \\
- \\
- \\
-\end{array}$ & $\begin{array}{l}- \\
- \\
- \\
- \\
- \\
- \\
\overline{-} \\
\overline{\text { Reduced }}\end{array}$ \\
\hline
\end{tabular}


TABLE III

HISTOCHEMICAL FINDINGS DURING TREATMENT WITH A GLUTEN-FREE DIET

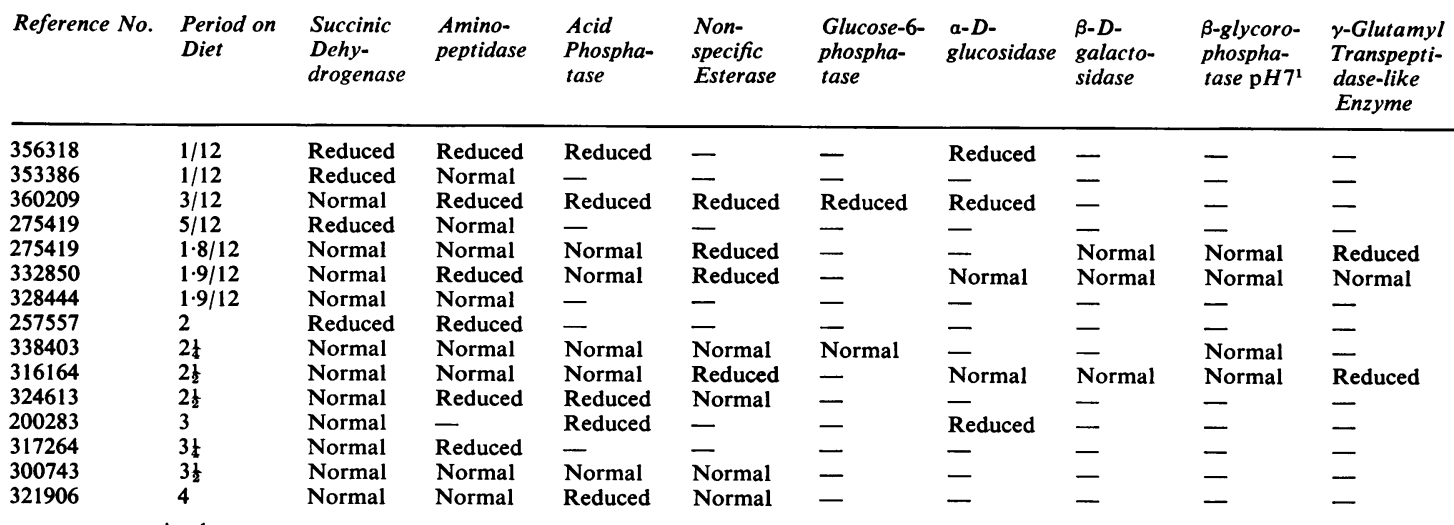

TABLE IV

HISTOCHEMICAL FINDINGS IN SIX CHILDREN ON A RESUMED NORMAL DIET FOLLOWING A GLUTEN-FREE DIET

\begin{tabular}{|c|c|c|c|c|c|c|c|}
\hline Reference No. & $\begin{array}{l}\text { Period on } \\
\text { Gluten-free } \\
\text { Diet }\end{array}$ & $\begin{array}{l}\text { Subsequent } \\
\text { Period on } \\
\text { Normal Diet }\end{array}$ & $\begin{array}{l}\text { Succinic } \\
\text { Dehydrogenase }\end{array}$ & $\begin{array}{l}\text { Amino- } \\
\text { peptidase }\end{array}$ & $\begin{array}{l}\text { Acid } \\
\text { Phosphatase }\end{array}$ & $\begin{array}{l}\text { Non-specific } \\
\text { Esterase }\end{array}$ & $\begin{array}{l}\text { K-Glutamyl } \\
\text { Transpeptidase- } \\
\text { like Enzyme }\end{array}$ \\
\hline 280013 & $18 / 12$ & 2 & Reduced & Reduced & - & - & - \\
\hline 321906 & 4 & $9 / 12$ & Reduced & Reduced & Reduced & Reduced & Reduced \\
\hline 206887 & 2 & 8 & Reduced & Normal & Reduced & - & - \\
\hline 256148 & $3 \frac{1}{2}$ & 1 & Reduced & Reduced & - & - & - \\
\hline 304397 & $14 / 12$ & 2 & Absent & Absent & - & - & - \\
\hline 296750 & $15 / 12$ & $2 \frac{1}{2}$ & Absent & Absent & - & - & - \\
\hline
\end{tabular}

$-=$ not examined

production tended roughly to keep pace with improvement in the morphology of the intestinal mucosa.

Table IV records the results obtained from six biopsies on children after they had returned from a gluten-free to a normal diet. It so happens that each of these children had given clinical evidence that they were still intolerant of gluten, and the histological appearance of each biopsy showed villous atrophy. As might perhaps be expected, in each case the enzymes studied were either reduced in amount or absent.

We have concluded that villous atrophy, whether it be present before beginning treatment with a gluten-free diet, or when it recurs, together with a return of clinical symptoms, after resumption of a normal diet, is associated with a reduction in enzyme production. During treatment with a gluten-free diet, improvement in the mucosal morphology is accompanied by improved enzyme production.

Histochemical methods Acid phosphatase (lead) was estimated by a modified Gomori method and also by an azocoupling method; amino-peptidase using 1-leucyl-4 methoxy-beta-naphthylamide substrate; esterase using $\alpha$-naphthylacetate substrate; $\beta$ - galactosidase (6-bromo-2-naphthyl-beta-D-galactopyranoside) substrate and glucose- 6 phosphatase by the Wachstein and Meisl method. The above techniques were applied as described in 'Histochemistry, theoretical and applied' (Pearse, 1960).

Succinic dehydrogenase was estimated by the M.T.T. method (Thomas and Pearse, 1961); $\beta$ glycero-phosphatase by the method of Wachstein (1955); $\alpha$-D-glucosidase (6-bromo-2-naphthyl-alphaD-glucopyranoside substrate) by the method of Rutenberg, Goldberg, Rutenberg, and Lang (1960); and $\gamma$-glutamyl transpeptidase-like enzyme by the method of Glenner, Folk, and McMillan (1962).

\section{DISACCHARIDE ENZYMES}

If, as has been shown, those enzymes of the intestinal mucosa demonstrable by histochemical methods are reduced, it might be expected that the disaccharidesplitting enzymes would be similarly affected. Gryboski, Thayer, Gabrielson, and Spiro (1963) investigated the urine chromatographically of four coeliac children between 11 months and 4 years of age, and found that while they were on normal diets 
all were passing abnormal amounts of lactose and sucrose, but a fortnight after giving a gluten-free diet the disacchariduria had cleared up. Their investigation of five adults with coeliac disease showed that after giving loading doses of the appropriate sugars the amount of lactose and sucrose in the urine was above that of normal controls. They also found abnormal amounts of both sugars in the urine of patients with cystic fibrosis of the pancreas and regional ileitis. Holzel (1964) reported a coeliac child aged 9 months with gross malabsorption of lactose, sucrose, and maltose, in whom a gluten-free diet led to a gradual amelioration of disaccharide malabsorption. He remarked 'disaccharide malabsorption in coeliac disease has been suspected, in some ways implied, but not previously proven. We have since investigated a number of patients with coeliac disease and have found that disaccharide malabsorption is a constant nutritional aspect of the disease and seems to correspond with the degree of severity.'

Shmerling, Auriochio, Ruoino, Hadorn, and Prader (1964) in a study of 19 coeliac children and 17 controls, showed a correlation between mucosal atrophy and a significantly lowered disaccharidase activity (lactase, invertase, maltase, and isomaltase), particularly affecting lactase, and they concluded that in the florid phase of the disease lactose should be avoided as well as gluten.

We report here the results of testing small intestine biopsy material from coeliac children for the presence of lactase, and in some of the cases invertase and maltase as well. The investigation was carried out by Dr. A. D. Patrick of the Biochemical Department of The Hospital for Sick Children. He describes his technique as follows:-

The frozen biopsy was homogenized in 10 vol. of icecold $0.9 \% \mathrm{NaCl}$. solution. Homogenate $(20 \mu 1$.$) was$ incubated at $37^{\circ} \mathrm{C}$. with $5 \mu \mathrm{l}$. of $0.1 \mathrm{M}$. lactose in $0.1 \mathrm{M}$. maleate buffer, $p \mathrm{H} \mathrm{6.5}$. At zero time $5 \mu \mathrm{l}$. of the mixture was applied directly to Whatman 3MM. paper for chromatography. Further samples were taken at suitable intervals (usually half, one, and two hours) during a two-hour incubation period. After equilibration for four hours, chromatograms were developed overnight by descending flow with the solvent system, ethyl acetate-pyridine-water (12: 5: 4: by vol.) Sugars were located with aniline-diphenylamine reagent.

Biopsies obtained from possible cases of malabsorption, in which the histological appearance was normal, were used as controls. Hydrolysis of lactose could be detected after incubation with these specimens for 10 minutes. Comparison with this rate of hydrolysis gave a semi-quantitative measure of lactase activity in the coeliac biopsies.

Seventeen biopsy specimens were examined from 13 coeliac children, and the findings are set out in
Table V. The table also shows the type of diet that was being given at the time of biopsy, and the histological appearance of the mucosa. Ten of the specimens were taken from children before they began a gluten-free diet; in all the mucosa showed subtotal villous atrophy; lactase activity could not be detected in eight, and in the other two its activity was weak, estimated at $20 \%$ of normal. Invertase, investigated in six, showed considerable reduction of activity, but was detectable. Maltase was tested for in two cases, and was less affected.

Six specimens were taken from children during the course of treatment with a gluten-free diet; five of them had been so treated for from one to seven months, and the findings did not differ from those of the previous group. The sixth child had received a gluten-free diet for two and a half years; the mucosa histologically showed partial villous atrophy, and lactase was clearly demonstrated, its activity estimated at $40 \%$ of normal.

The last specimen was from a boy of 7 years, who had resumed a normal diet for two months following four and a half years on a gluten-free diet.Clinically it was evident that he was still intolerant of gluten; his mucosa had reverted from being near normal to subtotal villous atrophy; no lactose activity could be detected, invertase showed only a weak activity, but maltase gave a strong action.

We have concluded that in coeliac children the pathological changes in the intestinal mucosa are associated with reduction in the activity of lactase and invertase, lactase being the more severely affected; indeed before a gluten-free diet lactase activity may be undetectable, but tends slowly to recover during gluten-free treatment. It seems likely that these enzyme deficiencies are secondary to the histological changes in the mucosa.

The presence of sugars in the urine of these children has been studied by chromatographic analysis. At the time of making the diagnosis and before beginning treatment the majority have shown abnormally high levels of lactosuria and sucrosuria, with normal levels of monosaccharides. After a few months of treatment lactosuria and sucrosuria have returned to normal levels.

Reduction in lactase and invertase, and the consequent appearance of abnormal amounts of lactose and sucrose in the urine has clinical repercussions. In previous communications (Sheldon, 1955; 1959) it has been pointed out that severely ill coeliac children may respond but poorly to the simple withdrawal of gluten from the diet, and that a much more restricted diet of skimmed milk, a high-protein food such as Prosol, glucose, and banana purée may be required for a few weeks before a fuller diet avoiding gluten can be built up. It seems likely that 
TABLE V

\begin{tabular}{|c|c|c|c|c|c|c|}
\hline \multirow[b]{2}{*}{ Reference No. } & \multirow[b]{2}{*}{ Age at Biopsy } & \multicolumn{3}{|c|}{ DISACCHARIDE ENZYMES } & \multirow[b]{2}{*}{ Invertase } & \multirow[b]{2}{*}{ Maltase } \\
\hline & & Diet $^{1}$ & $\begin{array}{l}\text { Histological } \\
\text { Appearance }\end{array}$ & Lactase & & \\
\hline 359979 & $11 / 12$ & I & S.V.A. & $\begin{array}{l}\text { No activity } \\
\text { detected }\end{array}$ & $\begin{array}{l}\text { Considerable } \\
\text { reduction }\end{array}$ & Good activity \\
\hline 364295 & $9 / 12$ & $\mathbf{I}$ & S.V.A. & $\begin{array}{l}\text { No activity } \\
\text { detected }\end{array}$ & - & - \\
\hline 365820 & $16 / 12$ & I & S.V.A. & $\begin{array}{l}\text { No activity } \\
\text { detected }\end{array}$ & Trace only & - \\
\hline 353444 & $18 / 12$ & I & S.V.A. & $\begin{array}{l}\text { No activity } \\
\text { detected }\end{array}$ & Greatly reduced & - \\
\hline 373680 & $21 / 12$ & I & S.V.A. & $\begin{array}{l}\text { No activity } \\
\text { detected }\end{array}$ & - & - \\
\hline 364295 & $7 \ddagger$ & I & S.V.A. & $\begin{array}{l}\text { Greatly reduced, } \\
\text { estimated } 20 \% \\
\text { of normal }\end{array}$ & - & - \\
\hline 363815 & 113 & I & S.V.A. & $\begin{array}{l}\text { No activity } \\
\text { detected }\end{array}$ & $\begin{array}{l}\text { Estimated } 10 \% \\
\text { of normal }\end{array}$ & - \\
\hline 359600 & $12 / 12$ & I & S.V.A. & $\begin{array}{l}\text { No activity } \\
\text { detected }\end{array}$ & Greatly reduced & Probably reduced \\
\hline 359600 & $19 / 12$ & II for $7 / 12$ & S.V.A. & $\begin{array}{l}\text { Trace estimated, } \\
\text { less than } 5 \% \\
\text { of normal }\end{array}$ & - & - \\
\hline 370881 & $15 / 12$ & I & S.V.A. & $\begin{array}{l}\text { No activity } \\
\text { detected }\end{array}$ & - & - \\
\hline 370881 & $19 / 12$ & II for $4 / 12$ & S.V.A. & $\begin{array}{l}\text { No activity } \\
\text { detected }\end{array}$ & - & - \\
\hline 360209 & $15 / 12$ & I & S.V.A. & $\begin{array}{l}\text { Estimated } 20 \% \\
\text { of normal }\end{array}$ & $\begin{array}{l}\text { Marked } \\
\text { reduction }\end{array}$ & - \\
\hline 360209 & $18 / 12$ & II for $3 / 12$ & S.V.A. & $\begin{array}{l}\text { Estimated } 20 \% \\
\text { of normal }\end{array}$ & $\begin{array}{l}\text { Marked } \\
\text { reduction }\end{array}$ & - \\
\hline 353386 & $13 / 12$ & II for $1 / 12$ & S.V.A. & $\begin{array}{l}\text { No activity } \\
\text { detected }\end{array}$ & - & - \\
\hline 353386 & $17 / 12$ & II for $5 / 12$ & P.V.A. & $\begin{array}{l}\text { Detectable } \\
\text { but weak }\end{array}$ & - & - \\
\hline 338255 & $3 \frac{1}{2}$ & II for $2 \frac{1}{2}$ yrs. & P.V.A. & $\begin{array}{l}\text { Clearly demon- } \\
\text { strated, estimated } \\
40 \% \text { of normal }\end{array}$ & - & - \\
\hline 330743 & 7 & $\begin{array}{l}\text { III for } 2 / 12 \\
\text { after } 4 \frac{1}{2} \text { yrs. } \\
\text { on gluten-free } \\
\text { diet. }\end{array}$ & S.V.A. & $\begin{array}{l}\text { No activity } \\
\text { detected }\end{array}$ & Weak activity & Strong activity \\
\hline
\end{tabular}

the difficulty for these children lies largely in their inability to split lactose and sucrose, and it has been our recent experience that when dealing with a child severely ill with coeliac disease, in addition to withdrawing all gluten from the diet, a low-lactose milk and avoidance of sucrose may also be required for several weeks. The return of sucrose to the diet can usually precede the return of lactose. Of the 10 children who feature in Table $\mathrm{V}$, and were investigated before treatment began, five were started on a gluten-lactose-sucrose-free diet, and made rapid improvement. In the others, although lactase activity in the biopsy was either greatly reduced or not detectable, the degree of lactosuria was less severe, and four of them made good progress when gluten alone was withdrawn; the fifth, with a urinary lactose level of $90 \mathrm{mg}$. \%, had to be reduced to a skimmed milk-prosol-glucose-banana régime for some weeks before eventually going ahead on a gluten-free diet. This difficult period would probably have been avoided or shortened if initially lactose and sucrose had been withdrawn.

\section{CONCLUSIONS}

Peroral small intestine biopsy gives a higher rate of failed attempts in children than in adults, and the 2-5-year age group is the most difficult.

It must be regarded as inevitable that in a blind procedure such as peroral intestinal biopsy, serious complications will occur from time to time. It is therefore essential to incorporate in the technique such measures as shall detect a complication as quickly as possible, and there must be facilities at hand to deal with it. Otherwise the investigation would be difficult to justify. Sufficient data have by now been reported on the results obtained from coeliac children to put this investigation outside the scope of a routine procedure.

Villous atrophy is always present in untreated 
coeliac children, and therefore when the diagnosis is in doubt biopsy offers a means of confirming or refuting the diagnosis, and can thus resolve the question of whether a long period of special dieting must be instituted. When the clinical diagnosis is not in doubt a biopsy is unnecessary.

The mucosal changes tend to revert towards normal during treatment with a gluten-free diet, but this is not invariable, and there is no clear time relation between the rate of mucosal recovery and the improvement in the clinical state, the latter outpacing the former. Biopsy is of little value as an indication whether a child is ready to resume a normal diet. This remains a matter of trial and error.

Although the mucosa may revert towards atrophy after a normal diet has been resumed, this is not necessarily accompanied by clinical relapse. The clinical effect of returning to a normal diet should be judged on clinical observations.

Dissection microscopy of the mucosa offers a rapid but only approximate appraisal of what the histological appearance is likely to be.

Histochemical studies indicate that mucosal atrophy, whether present before a gluten-free diet is instituted, or whether accompanying clinical relapse after resumption of a normal diet, is associated with a reduction in enzyme production. Improvement in the mucosal morphology is accompanied by increased enzyme production.

Mucosal atrophy is also accompanied by reduction is the activity of lactase and invertase, lactase being the more severely affected. The activity of these enzymes slowly recovers during treatment with a gluten-free diet. This may have repercussions on the management of the child severely ill with coeliac disease, for whom, in addition to a gluten-free diet, a period on a low-lactose milk and avoidance of sucrose may prove beneficial.

\section{REFERENCES}

Anderson, C. M. (1960). Histological changes in the duodenal mucosa in coeliac disease. Arch. Dis. Child., 35, 419-427.

Ashworth, C. T., Chears, W. C., Jr., Sanders, E., and Pearce, M. B. (1961). Nontropical sprue. Fine structure of the intestinal epithelial lesion. Arch. Path., 71, 31-19.

Brandborg, L. L., Rubin, C. E., and Quinton, W. E. (1959). A multipurpose instrument for suction biopsy of the esophagus, stomach, small bowel, and colon. Gastroenterology, 37. 1-16.

Cameron, A. H., Astley, R., Hallowell, M., Rawson, A. B., Miller, C. G., French, J. M., and Hubble, D. V. (1962). Duodenojejunal biopsy in the investigation of children with coeliac disease. Quart. J. Med., 31, 125-140.

Crosby, W. H., and Kugler, H. W. (1957). Intraluminal biopsy of the small intestine. Amer. J. dig. Dis., 2, 236-241.

Filipe, I. S. (1962). Discussion. Intestinal Biopsy (Ciba Foundation Study Group, no. 14) edited by G. E. W. Wolstenholme Jr., and M. P. Cameron, pp. 104-105, Churchill, London.
Glenner, C. G., Folk, J. E., and McMillan, P. J. (1962). J. Histochem. Cytochem., 10, 481.

Gryboski, J. D., Thayer, W. R., Jr., Gabrielson, I. W., and Spiro, H. M. (1963). Disacchariduria in gastrointestinal disease. Gastroenterology, 45, 633-637.

Hartman, R. S., Butterworth, C. E., Jr., Hartman, R. E., Crosby, W. H., and Shirai, A. (1960). An electron microscopic investigation of the jejunal epithelium in sprue. Ibid., 38, 506-516.

Holmes, R., Hourihane, D. O' B., and Booth, C. C. (1961). Dissectingmicroscope appearances of jejunal biopsy specimens from patients with 'idopathic steatorrhoea'. Lancet, 1, 81-83.

Holzel, A. (1964). Nutritional consequences of altered carbo-hydrate absorption in infancy and childhood. Proc. Nutr. Soc., 23, 123-129.

Hubble, D. (1963). Diagnosis and management of coeliac disease in childhood. Brit. med., J., 2, 701-706.

Madanagopalan, N., Shiner, M., and Rowe, B. (1965). Measurements of small intestinal mucosa obtained by peroral biopsy. Amer. J. Med., 38, 42-53.

Padykula, H. A., Strauss, E. W., Ladman, A. J., and Gardner, F. H. (1961). A morphologic and histochemical analyses of the human jejunal epithelium in nontropical sprue. Gastroenterology, 40, 735-765.

Pearse, A. G. E. (1960). Histochemistry, Theoretical and Applied. Churchill, London.

Rubin, C. E. (1961). Malabsorption; celiac sprue. Ann. Rev. Med., 12, 39-54.

-, Brandborg, L. L., Phelps, P. C., and Taylor, H. C., Jr. (1960a). Studies of celiac disease. I. The apparent identical and specific nature of the duodenal and proximal jejunal lesion in celiac disease and idiopathic sprue. Gastroenterology, 38, 28-49.

,,,,---- Murray, C. V., Stemler, R., Howry, C., and Volwiler, W. (1960b). Studies of celiac disease II. The apparent irreversibility of the preximal intestinal patholcgy in celiac disease. Ibid., 38, 517-532.

Rutenberg, A. M., Goldoerg, J. A., Rutenberg, S. H., and Lang, R. T. (1960). J. Histochem. Cytochem., 8, 268.

Sakula, J., and Shiner, M. (1957). Coeliac disease with atrophy of the small-intestine mucosa. Lancet, 2, 876-877.

Shackleton, J., and Haas, L. (1962). Fatal peritonitis after jejunal biopsy with the Crosby capsule. Ibid., 2, 989-990.

Shearman, D. J. C., Girdwood, A. H., Williams, A. W., and Delamore, I. W. (1962). A sutdy with the electron microscope of the jejunal epithelium in primary malabsorptive disease. Gut, $3,16-25$.

Sheehy, T. W. (1964). Intestinal biopsy. Lancet, 1, 959-962.

Sheldon, W. (1955). Coeliac disease. Ibid., 2, 1097-1103.

- (1959). Celiac disease. Pediatrics, 23, 132-145.

Shiner, M. (1960). Histopathological findings in the small intestinal mucosa studied by a peroral biopsy technique. Gut., 1, 48-54.

- , and Birbeck, M. S. C. (1961). The microvilli of the small intestinal surface epithelium in coeliac disease and in idopathic steatorrhoea. Ibid., 2, 277-284.

-, and Doniach, I. (1960). Histopathologic studies in steatorrhea. Gastroenterology, 38, 419-440.

Shmerling, D. H., Auriochio, S,. Ruoino, A., Hadorn, B., and Prader, A. (1964). Der sekundäre Mangel au intestinaler Disaccharidase-aktivität bei der Cöliakie, Helv. paediat acta, 19, 507-527.

Spiro, H. M., Filipe, M. I., Stewart, J. S., Booth, C. C., and Pearse, A. G. E. (1964). Functional histochemistry of the small bowel mucosa in malabsorptive syndromes. Gut, 5, 145-154.

Thomas, E., and Pearse, A. G. E. (1961) Histochemie, 2, 266.

Thurlbeck, W. M., Benson, J. A., Jr., and Dudley, H. R., Jr. (1960). The histopathologic changes of sprue and their significance, Amer. J. clin., Path., 34, 108-117.

Townley, R. W. R., Cass, M. H., and Anderson, C. M. (1964). Small intestinal mucosal patterns of coeliac disease and idiopatic steatorrhoea seen in other situations. Gut, 5, 51-55.

Wachstein, M. (1955). J. Histochem, Cytochem. 3, 246.

Yardley, J. H., Bayless, T. M., Norton, J. H., and Hendrix, T. R. (1962). Celiac disease. A study of the jejunal mucosa before and after a gluten-free diet. New Engl. J. Med., 267, 1173-1179.

Zetterqvist, H., and Hendrix, T. R. (1960). A preliminary note on an ultrastructural abnormality of the intestinal epithelium in adult celiac disease (non-tropical sprue) which is reversed by a gluten free diet. Bull Johns Hopk, Hosp, 106, 240-249. 